\title{
Assessing the Impacts of HIV/AIDS Programmes on Sexual Health among the Youths of Obiyebe Community in Ogba/Ebgema/Ndoni Local Government Area of Rivers State
}

\author{
Udo Orukwowu* and Boma Iweriso George
}

\begin{abstract}
Department of Nursing Sciences, Faculty of Basic Medical Sciences, College of Medical Sciences, Rivers State University, Nigeria
\end{abstract}

*Corresponding author: udocd27@ gmail.com; Phone: +2349060039098

\begin{abstract}
This study assessed the impacts of HIV/AIDS programmes on sexual health among youths of Obiyebe community in Ogba/Egbema/Ndoni LGA of Rivers State. The purpose of the study was to identify HIV/AIDS programmes on sexual health, to assess the knowledge of HIV/AIDS programmes on sexual health among the youths and to examine the impacts of HIV/AIDS programmes on sexual health among youths. The study adopted a descriptive survey study design with a sample size of 83 participants which are selected through a simple random sampling technique. A structured questionnaire was used as the instrument for data collection, while a frequency table and simple percentage were used as the instrument for data analysis. The findings of the study revealed that HIV/AIDS programmes on sexual health are; HIV/AIDS testing programmes, HIV/AIDS treatment programmes, HIV/AIDS prevention programmes, and United Nations Programmes on HIV/AIDS (UNAIDS). Another finding of the study showed that sexuality, condoms, sexual anatomy and sex, and adolescence sexual features and puberty are the knowledge of sexual health among the youths that enhance their good sexual health and prevention of HIV/AIDS. Again the study revealed that the impacts of HIV/AIDS programmes on the sexual health of the youths were that their understanding of sexuality is increased, they understand the importance of using condoms if sexually active, there is a reduction in unwanted teenage pregnancies, they are informed of their normal sexual features development, puberty, reproductive anatomy and physiology, they are informed of the option to delay sexual activity until they are ready (matured), and there is a reduction of new HIV/AIDS/ other STI infections. The study made some recommendations and suggestions.
\end{abstract}

Keywords: HIV/AIDS; HIV/AIDS; Programmes; Sexual Health; Youths

\section{Article History}

Received: 20 Dec 2021

Accepted: 30 Dec 2021

Published: 05 Jan 2022
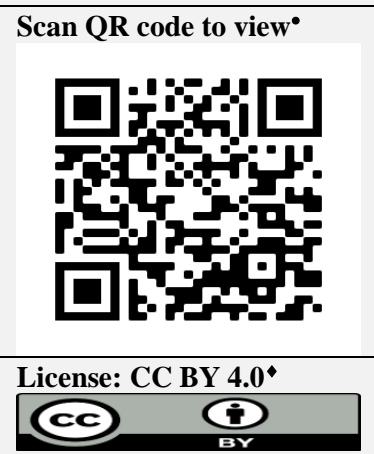

Open Access article.

How to cite this paper: Orokwowu, U. and George, B.I. (2022). Assessing the Impacts of HIV/AIDS Programmes on Sexual Health among the Youths of Obiyebe Community in Ogba/Ebgema/Ndoni Local Government Area of Rivers State. Scicom J Med Appl Med Sci, 1(1), 6-12. https://doi.org/10.54117/sjmams.v1i1.2

\section{Introduction}

HIV/AIDS is an acronym for Human Immune Virus/Acquired Immune Deficiency Syndrome. HIV/AIDS is a virus that targets and alters the immune system of the body, hence increasing the risk of the impact of other diseases and infections. It attacks the immune cells called CD4 cells which are of T-cell, thereby reducing the body's ability to combat other diseases (World Health Organization, WHO, 2017).

HIV/AIDS is the leading cause of death among youths (aged 10-24yrs) in Africa and the second leading cause globally. Young women are twice as likely to acquire HIV as young men. A youth bulge in Africa threatens to increase new HIV infection further and unprotected sex is the most common route of HIV infection among youths. Low HIV and sexual health knowledge is a key barrier to reducing HIV infection among the youths and a life cycle approach to HIV prevention can help respond to the changing challenges people face at different ages (United Nations Program on HIV/AIDS, UNAIDS, 2012).

HIV/AIDS is one of the most urgent public health challenges facing both developing and developed nations. Even though it affects all the social sectors of the population, the epidemic among youths is the fastest- growing partly because of youths' vulnerability and because of the low use of preventive services. Despite this, youths are also seen as a 'window of hope' because they have great potential for positive change of attitudes and behaviours (World Health Organization (WHO), 2014).

Focusing on youths is likely to be the most effective approach to confronting the epidemic, particularly in high prevalence countries. This was recognized at a global level by the 2001 UN General Assembly Special Session on HIV/AIDS who endorsed that "By 2003, establish time-bound national targets to achieve the internationally agreed global prevention goal to reduce by 2005 HIV prevalence among youths aged $15-24$ in the most affected countries by $25 \%$ and by $25 \%$ globally by 2010" (World Health Organization (WHO, 2013).

It is therefore not surprising that Venier et al (2018) reported in their study in Nigeria, Kenya and Zimbabwe that urban students had more information and knowledge about HIV than their counterparts in the rural areas. More studies reported in the following age groups of 15-19, 20-24 and 25- 29 show estimates of 4.9, 8.1 and 6.9 per cent prevalence. Nigeria bears about 8 per cent of the global and 10 per cent of Africa's HIV/AIDS burden. At the outset of this disease, the government's response was at 
best passive and the country was in denial about the epidemic. However, the responses over time by the government and non-governmental agencies have been considerable so far.

Lack of adequate knowledge has been implied as a major reason for highrisk heterosexual behaviour and in Nigeria, the most common mode of transmission of HIV is via sexual intercourse. Many papers have reiterated that multiple partners, early sexual experience and inconsistent use of condoms have been responsible for the rise in the disease among youths. These suggest that a positive attitude towards sexual health in youths or HIV/AIDS preventive strategies/measures could produce desirable behaviours and reduce risk (Nwokocha \& Nwakoby, 2012).

Youths constitute a considerable proportion of the world population $(32 \%)$. They are a rich human resource and an important part of the development process. The good health of the youths will help in raising the health status of the Community. They are highly vulnerable to human immunodeficiency virus (HIV)/acquired immunodeficiency syndrome (AIDS) and other sexually transmitted infections (STIs). The Health of adolescent girls has an intergenerational effect (Samuelsen, 2016).

A positive attitude towards sexual health in youths or HIV/AIDS preventive strategies/measures could produce desirable behaviours and reduce risk. HIV's natural history has a long latency period between acquisition of the infection and manifestation of the disease and this may suggest that a large proportion or percentage of individuals have been infected during youth or adolescence only to develop full-blown AIDS a number of years later. Adolescents including those of school age are identified as the group at the highest risk of acquiring the infection since they are sexually active, take greater risks and believe in their invulnerability (Allman, Adebajo, Myers, Odumuye \& Ogunsola, 2017). The focus on youths is because people aged between 15 and 24 years of age comprise about 20 per cent of the world's population and account for 60 per cent of the new HIV infections each year. Studies published on HIV have suggested that youths lack information adequate for them to make informed decisions about sexual behaviour and solutions to the consequent problems that arise from such behaviour. Youths may be aware of HIV, cultural traditions and inhibitions by parents prevent these youths from acquiring knowledge from their teachers and parents. Some other reasons suggested by literature include a high level of pre-marital, multiple, short term sexual relationships, vulnerability to sexual violence, and exploitation of females by older, richer men where there is an exchange for money, goods and sex, sexual abuse as well as poor assertiveness skills (Adeyi et al, 2010).

Many studies have shown high awareness about HIV/AIDS, other studies have shown that information and education are not enough to positively impact behaviour change. Unfortunately, Nigerian students have been shown in some studies to perceive AIDS as a highly dreaded disease which leads to avoidance of information and denial of risk (Okudo, 2012). World Health Organization (WHO) (2013) reported that HIV/AIDS has been one of the world's greatest challenges for decades. Sub-Saharan Africa bears the greatest burden of the disease even though it has only 10 per cent of the world's population. Nigeria has the second-largest number of people living with HIV/AIDS after South Africa in Sub-Saharan Africa. It is estimated that 60 per cent of all new HIV infections in Sub Saharan Africa occur among youths aged ten to twenty-four years of age. The first confirmed reports of HIV infection in Nigeria are in Lagos in 1985 and reported at an international conference in 1986. HIV prevalence estimates have continued to increase from 1.8 per cent in 1991 to 4.5 per cent in 1996 and 5.8 per cent in 2003. Many studies have suggested that the prevalence of HIV infection has crossed the critical epidemiological threshold of 5.0 percent. However, this figure did not change in 2003 but reduced to 5.4 per cent in 2005 and further to 4.8 per cent in 2006 However, it is important to note that the national data in 2001 are actual estimates from seroprevalence surveys conducted among pregnant women at 86 antenatal clinics which at that time served as sentine surveillance sites. Unfortunately, it can be argued that these data may not provide good measures of group-specific prevalence rates. These data do not explain anything about seroprevalence in men or children. In addition, no explanations are given about regional or rural or urban differences. Regional variations have been seen in some reports from United States Agency for International Development 2018 (USAID, 2018). For example states such as Benue (10.6\%) in the north-central part of Nigeria have higher prevalence rates than Ekiti state (1\%) in the southwestern part of Nigeria.
V/AIDS programmes are specially designed programmes that are geared towards creating awareness and educating people about HIV/AIDS and its prevention. HIV/AIDS programmes have a direct link with the sexual health of the youths, it enables the youths to exhibit good sexual behaviour to protect them from contracting HIV/AIDS virus which can affect their health. HIV/AIDS programmes provide an opportunity to the youths to know the causes of AIDS, its symptoms, mode of transmission, its health implications, treatment and prevention. The sexual behaviour of the youths has a significant relationship and influence with their health and this depends on their level of knowledge of HIV/AIDS which can be achieved through adequate HIV/AIDS programmes (Mbagwu \& Abali, 2017))

HIV programmes that are designed to improve knowledge and awareness about HIV and sexually transmitted infections (STIs) are often based on the premise that greater knowledge among youths will lead to changes in their sexual behaviour. However, some studies have reported the lack of association between HIV knowledge and sexual behaviour. On the other hand, social and cultural barriers, attitudes and practices seem to be the major determinants of youth's risky behaviour. Another premise is that use of protection will depend on the type of sexual partner, and while this premise may hold among adults, it is not clear that youths act in this same way (Adih \& Alexander, 2009).

HIV/AIDS programmes include; prevention programmes such as; prevention of mother-to-child transmission, voluntary medical male circumcision, prevention, pre-exposure prophylaxis and harm reduction programmes. Others are treatment programmes such as; HIV treatment, treatment cascade and HIV drug resistance. Emergencies and armed conflict are also other HIV/AIDS programmes. Furthermore, HIV and coinfections programmes include HIV/HeP C co-infection, HIV/TB coinfection. There is also HIV/AIDS testing programmes and technology and e-health programmes that are available for the youths and adults (Amuyunzu-Nyamongo, Biddlecom, Ouedraogo \& Woog, 2015).

Knowledge of sexual health among the youths such as adolescence and puberty, sexual anatomy and sex, sexuality, STIs/STDs, condoms, inclusive sex education and choosing not to be sexually active right now can contribute to some extent in enhancing good sexual health of the youths and prevention of HIV/AIDS (National Agency for the Control of AIDS (NACA), 2010).

Youths who exhibit bad sexual behaviour such as having unprotected sexual intercourse place themselves at the risk of contracting HIV/AIDS and other sexually transmitted diseases (STDs) and infection (STIs). Good sexual health of the youths is guaranteed when they show a positive attitude by putting on protective barriers such as condoms, diaphragm etc during sexual intercourse (Abiona \& Odu, 2018).

The impacts of HIV/AIDS programmes on the sexual health of the youths cannot be overemphasized. This is because it has created awareness of HIV/AIDS as related to the youth's sexual behaviour which negative resultant effects can adversely affect their sexual health. Furthermore, some of the impacts of HIV/AIDS programmes on the sexual health of the youths include; informing them of normal youths development, puberty and reproductive anatomy and physiology, increasing their understanding of sexuality, informing them of the option to delay sexual activity until they are ready, helping them to understand the importance of using condoms if sexually active, reducing new HIV and other STI infections etc (United Nations Program on HIV/AIDS (UNAIDS), 2012). A study conducted by Ijadunola (2017) on the impact of knowledge of HIV/AIDS programmes on the sexual health of the youths in Kenya. A descriptive survey research design was adopted and a sample size of 370 participants which was selected through a simple random sampling technique was employed in the study. A structured questionnaire was used as a method for data collection and frequency table and sample percentage was also used as a method of data analysis. The study reported that the impacts of HIV/AIDS programmes on the sexual health of the youths are; youths are informed on normal youths development, puberty and reproductive anatomy and physiology, youths understanding of sexuality is increased, the youths are informed of the option to delay sexual activity until they are ready (matured), HIV/AIDS programmes help the youths to understand the importance of using condoms if sexually active, there is a reduction of new HIV/AIDS/ other STI infections, there is also a reduction in unwanted teenage pregnancies. 


\section{Methodology}

\section{Study Area}

This study was conducted in Obiyebe Community in Ogba/Ebema/Ndoni Government Area of Rivers State. Obiyebe Community is geographically located at latitude $15^{\circ} 15 \mathrm{~N}, 20^{\circ} 23$ and latitude $15^{\circ} 30^{\mathrm{II}}, 12^{\circ} 45^{\mathrm{II}} \mathrm{E}$. It shared boundaries with Akabuka/Ogbogu town on the West, Akabta Community on the East, Erema Community on the South and Obite Community on the North.

The inhabitants of the Community are predominantly engaged in farming, business, commercial and industrial activities and civil service respectively.

\section{Research Design.}

The study adopted a descriptive survey research design. The study was conducted between May, 2021 and June, 2021 to access the impacts of HIV/AIDS programmes on the sexual health among the youths of Obiyebe Community in Onelga, Rivers State

\section{Study Population}

The study population comprised all the youths both male and female between the age limit of $10-48$ yrs residing in Obiyebe Community in Onelga, Rivers State numbering 500 persons.

\section{Sampling Size/Sampling Technique}

A total of 83 persons are sampled for the assessment of the impacts of HIV/AIDS programmes on sexual health among the youths of Obiyebe Community in Onelga, Rivers State using Yamen Taro's formula for determining sample size as stated below;

Sample size;

Where: $\mathrm{n}=$ Sample size

$$
n=\frac{N}{1+N(e)^{2}}
$$

$\mathrm{N}=$ Total population for the study $=500$

$\mathrm{e}=$ Level of significance error term at $5 \%(95 \%$ confidence interval $)=$ 0.10

A Simple random sampling technique was used to select the participants

\section{Instrument for Data Collection}

The instrument used for data collection was a structured questionnaire. (Fixed - response type close-ended questionnaire).

\section{Method of Data Collection}

The researcher administered 83 copies of the questionnaire directly (faceface) to all the participants. Copies of the questionnaire are collected on the spot after completion.

\section{Method of Data Analysis}

The data collected from this study are subjected to statistical analysis using statistical package for social sciences (SPSS) of windows (version 20.0). Frequency table and simple percentage are also used for analyzing the data.

\section{Ethical Consideration}

The researcher received approval letter from the ethical committee, department of public health, Rivers State College of Health Science and Management Technology, Port Harcourt, which enables him to conduct research in the study area.

\section{Results}

The results are stated in tables 1-8. Information in these tables indicated the responses to research questions 1-3 and subsequently ensures the achievement of the study-specific objectives. Table 1, showed that the respondents' whose age limit fall between $10-12$ years are $14(16.9 \%)$, the ones within the age bracket of $13-15$ years are 26(31.3\%), the group between the ages of $16-18$ years had a frequency of $28(37.7 \%)$, which form the majority of the respondents', while those within the age limit of 19 yrs and above are $15(18.1 \%)$
Table 1: Respondents' Age

\begin{tabular}{|l|l|l|}
\hline Age limit & Frequency & Percentage (\%) \\
\hline $10-12$ yrs & 14 & 16.9 \\
\hline $13-15$ yrs & 26 & 31.3 \\
\hline $16-18$ yrs & 28 & 37.7 \\
\hline 19 yrs-above & 15 & 18.1 \\
\hline Total & $\mathbf{8 3}$ & $\mathbf{1 0 0}$ \\
\hline
\end{tabular}

Table 2 revealed that $40(48.2 \%)$ of the respondents' are male while, $43(51.8 \%)$ are female, hence majority of the respondents' are female.

Table 2: Respondents' Gender

\begin{tabular}{|l|l|l|}
\hline Gender & Frequency & Percentage (\%) \\
\hline Male & 40 & 48.2 \\
\hline Female & 43 & 51.8 \\
\hline Total & $\mathbf{8 3}$ & $\mathbf{1 0 0}$ \\
\hline
\end{tabular}

Table 3 highlighted that $50(60.2 \%)$ of the respondents' are single which makes the majority of the total respondents', 20(24.1\%) are married, $8(9.6 \%)$ of the respondents' are divorced, while $2(2.4 \%)$ are widow/widower, and 3(3.6\%) are separated.

Table 3: Respondents' Marital Status.

\begin{tabular}{|l|l|l|}
\hline Marital Status & Frequency & Percentage (\%) \\
\hline Single & 50 & 60.2 \\
\hline Married & 20 & 24.1 \\
\hline Divorced & 8 & 9.6 \\
\hline Widow/Widower & 2 & 2.4 \\
\hline Separated & 3 & 3.6 \\
\hline Total & $\mathbf{8 3}$ & $\mathbf{1 0 0}$ \\
\hline
\end{tabular}

Table 4, showed that $10(12.0 \%)$ of the respondents' had non-formal education, $20(24.1 \%)$ had primary education, $35(42.1 \%)$ had secondary education, which form the bulk of the respondents' and 18(21.8\%) had tertiary education respectively.

Table 4: Respondents' Level of Education

\begin{tabular}{|l|l|l|}
\hline Level of Education & Frequency & Percentage (\%) \\
\hline Non - formal & 10 & 12.0 \\
\hline Primary & 20 & 24.1 \\
\hline Secondary & 23 & 42.1 \\
\hline Tertiary & 18 & 21.8 \\
\hline Total & $\mathbf{8 3}$ & $\mathbf{1 0 0}$ \\
\hline
\end{tabular}

Information obtained from table 5 revealed that $69(83.1 \%)$ of the respondents' are Christians, which makes the majority of the total respondents', 1(1.2\%) are Islamic worshippers, while 6(7.2\%) are traditionalist and $7(8.5 \%)$ worship other religions.

Table 5: Respondents' Religion.

\begin{tabular}{|l|l|l|}
\hline Religion & Frequency & Percentage (\%) \\
\hline Christianity & 69 & 83.1 \\
\hline Islam & 1 & 1.2 \\
\hline Traditionalist & 6 & 7.2 \\
\hline Others & 7 & 8.5 \\
\hline Total & $\mathbf{8 3}$ & $\mathbf{1 0 0}$ \\
\hline
\end{tabular}

Research Questions.

I. What are the HIV/AIDS Programmes on Sexual Health?

Table 6 indicated that the mean score of the respondents who said that HIV/AIDS prevention programmes (i.e.) voluntary medical male circumcision is one of the HIV/AIDS Programmes on Sexual Health was $63(75.9 \%)$, while those who opposed the statement had a mean score of $20(24.1 \%)$. Also, $68(81.9 \%)$ was the mean score of the respondents who said that United Nations Programmes on HIV/AIDS (UNAIDS) is another programme on HIV/AIDS and those who objected to the statement had a mean score of $12(18.1 \%)$. Furthermore, the respondent who agreed that another programme on HIV/AIDS is HIV/AIDS treatment programmes had a mean score of $77(92.8 \%)$ and those who disagreed with the statement had a mean score of 16(7.2\%). In a similar vein, the respondents' who confirmed the statement that HIV/AIDS testing programmes is also among the HIV/AIDS programmes had a mean score of $83(100.0 \%)$, while the respondents' who disagreed with 
that statement had a mean score of $0(0 \%)$. Similarly, 35(42.2\%) was the mean score of the respondents' who affirmed that technology and e-health programmes are included in the HIV/AIDS programmes, while those who opposed the statement had a mean score of $48(57.8 \%)$.

Table 6: Showing HIV/AIDS Programmes on Sexual Health $(\mathrm{n}=83)$.

\begin{tabular}{|l|l|l|l|l|l|l|l|}
\hline S/n & Items & A & S.A & $\bar{X}$ & D & S.D & $\bar{X}$ \\
\hline 1 & $\begin{array}{l}\text { HIV/AIDS } \\
\text { prevention } \\
\text { programmes } \\
\text { (i.e.) } \\
\text { voluntary } \\
\text { medical male } \\
\text { circumcision. }\end{array}$ & 25 & 38 & $63(75.9 \%)$ & 7 & 13 & $20(24.1 \%)$ \\
\hline 2 & $\begin{array}{l}\text { United } \\
\text { Nations } \\
\text { Programmes } \\
\text { on } \\
\text { HIV/AIDS } \\
\text { (UNAIDS). }\end{array}$ & 22 & 46 & $68(81.9 \%)$ & 9 & 3 & $12(18.1 \%)$ \\
\hline 3 & $\begin{array}{l}\text { HIV/AIDS } \\
\text { treatment } \\
\text { programmes }\end{array}$ & 48 & 29 & $77(92.8 \%)$ & 2 & 14 & $16(7.2 \%)$ \\
\hline 4. & $\begin{array}{l}\text { HIV/AIDS } \\
\text { testing } \\
\text { programmes }\end{array}$ & 50 & 33 & $83(100.0 \%)$ & - & - & - \\
\hline 5 & $\begin{array}{l}\text { Technology } \\
\text { and e-health } \\
\text { programmes }\end{array}$ & 14 & 21 & $35(42.2 \%)$ & 32 & 16 & $48(57.8 \%)$ \\
\hline
\end{tabular}

II. What is the Knowledge of Sexual Health among the Youths which enhance their Good Sexual Health and Prevention of HIV/AIDS?

Table 7. revealed that the respondents' who said that adolescence and puberty is one the knowledge of sexual health among the youths which enhance their good sexual health and prevention of HIV/AIDS had a mean score of $65(78.3 \%)$, while those who opposed the statement had a mean score of $73(88.0 \%)$. Also, 83(100.0\%) was the mean score of the respondents who said that sexual anatomy and sex was one of the knowledge of sexual health among youths which enhance their good sexual health and prevention of HIV/AIDS and those who objected to that statement had a mean score of $0(0 \%)$. Furthermore, the respondent who agreed that sexuality was another knowledge of sexual health among the youths which enhance their good sexual health and prevention of HIV/AIDS had a mean score of $23(27.7 \%)$ and those who disagreed with the statement had a mean score of $0(0 \%)$. In a similar vein, the respondents' who confirmed the statement that STIs/STDs was also inclusive knowledge of sexual health among the youths which enhance their good sexual health and prevention of HIV/AIDS had a mean score of $23(27.7 \%)$, while those who disagreed with that statement had a mean score of $60(72.3 \%)$. Similarly, 74(89.2\%) was the mean score of the respondents' who affirmed that condoms were also inclusive knowledge of sexual health among the youths which enhance their good sexual health and prevention of HIV/AIDS, while those who opposed the statement had a mean score of $9(10.8 \%)$. Again, 36(43.4\%) was the mean score of the respondents who said that another knowledge of sexual health among the youths which enhance their good sexual health and prevention of HIV/AIDS was Inclusive sex, while those who disagreed with that statement had a mean score of $47(56.6 \%)$. Subsequently, the table under review disclosed that the respondents' who said that choosing not to be sexually active right now was one of the knowledge of sexual health among the youths which enhance their good sexual health and prevention of HIV/AIDS had a mean score of $48(57.8 \%)$ and those who objected that statement had a mean score of $35(42.2 \%)$.
Table 7: Showing Respondents' Response to Knowledge of Sexual Health among the Youths $(n=83)$

\begin{tabular}{|l|l|l|l|l|l|l|l|}
\hline S/n & Items & A & S.A & $\bar{X}$ & D & S.D & $\bar{X}$ \\
\hline 7 & $\begin{array}{l}\text { Adolescence } \\
\text { and puberty }\end{array}$ & 37 & 28 & $65(78.3 \%)$ & 6 & 12 & $18(21.7 \%)$ \\
\hline 8 & $\begin{array}{l}\text { Sexual anatomy } \\
\text { and sex. }\end{array}$ & 53 & 20 & $73(88.0 \%)$ & 2 & 8 & $10(12.0 \%)$ \\
\hline 9 & $\begin{array}{l}\text { Sexuality. } \\
10\end{array}$ & 59 & 24 & $83(100 \%)$ & - & - & - \\
\hline 11 & $\begin{array}{l}\text { STIs/STDs } \\
\text { Condoms }\end{array}$ & 4 & 19 & $23(27.7 \%)$ & 40 & 20 & $60(72.3 \%)$ \\
\hline 12 & $\begin{array}{l}\text { Inclusive sex } \\
\text { education. }\end{array}$ & 15 & 21 & $36(43.4 \%)$ & 25 & 22 & $47(56.6 \%)$ \\
\hline 13 & $\begin{array}{l}\text { Choosing not to } \\
\text { be sexually } \\
\text { active right } \\
\text { now. }\end{array}$ & 12 & 27 & $48(57.8 \%)$ & 31 & 3 & $35(42.2 \%)$ \\
\hline
\end{tabular}

III. What are the Impacts of HIV/AIDS Programs on Sexual Health of the Youths?

Table 8 indicated that the mean score of the respondents who said that one of the impacts of HIV/AIDS programs on the sexual health of the youths was that they are informed of their normal sexual features development, puberty, and reproductive anatomy and physiology was $67(81.9 \%)$, while those who opposed the statement had a mean score of $16(19.3 \%)$. Also, $83(100 \%)$ was the mean score of the respondents who said that youths understanding of sexuality is increased and no respondent opposed the statement. Furthermore, the respondents' who agreed that another impact of HIV/AIDS programs on the sexual health of the youths was that the youths are informed of the option to delay sexual activity until they are ready (matured) had a mean score of $64(77.1 \%)$ and those who disagree with the statement had a mean score of 19(22.9\%). In a similar vein the respondents' who confirmed the statement that HIV/AIDS programmes help the youths to understand the importance of using condoms if sexually active had a mean score of $73(88.0 \%)$, while the respondents' who disagreed with that statement had a mean score of $10(12.0 \%)$. Similarly, 61(73.5\%) was the mean score of the respondents' who affirmed that there is a reduction of new HIV/AIDS/ other STI infections, while those who opposed the statement had a mean score of $12(26.5 \%)$. Again the respondents' who said that there is also a reduction in unwanted teenage pregnancies had a mean score of 70(84.3\%), and those who refuted the statement had a mean score of $13(15.7 \%)$ respectively.

\section{Discussion}

This study assessed the impacts of HIV/AIDS programmes on the sexual health among the youths of Obiyebe Community in Ogba/Ebgema/Ndoni Local Government Area Of Rivers State

Research Question 1: What are the HIV/AIDS Programmes on Sexual Health?

The finding of research question 1 as shown in table 6 indicated that HIV/AIDS Programmes on Sexual Health are; HIV/AIDS testing programmes (100.0\%), HIV/AIDS treatment programmes (92.8\%), HIV/AIDS prevention programmes (i.e.) voluntary medical male 
circumcision(75.9\%) and United Nations Programmes on HIV/AIDS (UNAIDS) $(81.9 \%)$

Table 8: Showing the Impacts of HIV/AIDS Programs on Sexual Health of the Youths $(n=83)$.

\begin{tabular}{|c|c|c|c|c|c|c|c|}
\hline & Items & A & S.A & $\bar{x}$ & $\mathrm{D}$ & S.D & $\bar{x}$ \\
\hline 1 & $\begin{array}{l}\text { Youths are } \\
\text { informed of } \\
\text { their normal } \\
\text { sexual features } \\
\text { development, } \\
\text { puberty and } \\
\text { reproductive } \\
\text { anatomy and } \\
\text { physiology. }\end{array}$ & 50 & 18 & $67(81.9 \%)$ & 4 & 12 & $16(19.3 \%)$ \\
\hline 2. & $\begin{array}{l}\text { Youths } \\
\text { understanding } \\
\text { of sexuality are } \\
\text { Increased. }\end{array}$ & 60 & 23 & $83(100.0 \%)$ & - & - & - \\
\hline 3 & $\begin{array}{l}\text { The youths are } \\
\text { informed of the } \\
\text { option to delay } \\
\text { sexual activity } \\
\text { until they are } \\
\text { ready } \\
\text { (matured). }\end{array}$ & 35 & 29 & $64(77.1 \%)$ & 10 & 9 & $19(22.9 \%)$ \\
\hline 4. & $\begin{array}{l}\text { HIV/AIDS } \\
\text { programmes } \\
\text { help the youths } \\
\text { to } \\
\text { understand the } \\
\text { importance of } \\
\text { using condoms } \\
\text { if sexually } \\
\text { active. }\end{array}$ & 41 & 32 & $73(88.0 \%)$ & 3 & 7 & $10(12.0 \%)$ \\
\hline 5. & $\begin{array}{l}\text { There is } \\
\text { reduction of } \\
\text { new HIV/AIDS/ } \\
\text { other STI } \\
\text { infections. }\end{array}$ & $\begin{array}{l}1 \\
27\end{array}$ & 34 & $61(73.5 \%)$ & 6 & 6 & $12(26.5 \%)$ \\
\hline 6. & $\begin{array}{l}\text { There is also } \\
\text { reduction in } \\
\text { unwanted } \\
\text { teenage } \\
\text { pregnancies }\end{array}$ & 39 & 31 & $70(84.3 \%)$ & 5 & 8 & $13(15.7 \%)$ \\
\hline
\end{tabular}

This finding is in line with the study of Amuyunzu-Nyamongo, Biddlecom, Ouedraogo \& Woog, 2015) on HIV/AIDS prevention programmes: global perspective and strategies. The results of the study reported that HIV/AIDS programmes include; prevention programmes, pre-exposure prophylaxis and harm reduction programmes, treatment programmes, emergencies and armed conflict programmes, HIV and coinfections programmes, HIV/AIDS testing programmes and technology and e-health programmes.

Research Question 2: What is the Knowledge of Sexual Health among the Youths?

Similarly, the finding of this study in respect to research question 2 above in table 7 showed that sexuality $(100 \%)$, condoms $(89.2 \%)$, sexual anatomy and sex (88.0\%) and adolescence and puberty (78.3\%) are the knowledge of sexual health among the youths which enhance their good sexual health and prevention of HIV/AIDS. This finding is supported by the finding of the study conducted by ((National Agency for the Control of AIDS (NACA) (2010) on 'National HIV/AIDS strategic framework (NSF): knowledge of sexual health among the youths. The result of the study indicated that adolescence and puberty, sexual anatomy and sex, sexuality, STIs/STDs, condoms, inclusive sex education and choosing not to be sexually active right now are the knowledge of sexual health among the youths

Research Question 3: What are the Impacts of HIV/AIDS Programmes on Sexual Health of the youths?

Additionally, on research question 3 above, another finding of this study, according to table 8 revealed that the impacts of HIV/AIDS programs on the sexual health of the youths were that youths understanding of sexuality is increased $(100 \%)$, youths understand the importance of using condoms if sexually active $(88.0 \%)$, there is a reduction in unwanted teenage pregnancies (84.3\%). youths are informed of their normal sexual features development, puberty, and reproductive anatomy and physiology $(81.9 \%)$, youths are informed of the option to delay sexual activity until they are ready (matured) (77.1\%), and reduction of new HIV/AIDS/ other STI infections (73.5\%), This finding is corroborated with the study conducted by Ijadunola (2017) on the impact of knowledge of HIV/AIDS programmes on the sexual health of the youths in Kenya. The study reported that the impacts of HIV/AIDS programmes on the sexual health of the youths are; youths are informed on normal sexual features development, puberty and reproductive anatomy and physiology, youths understanding on sexuality is increased, the youths are informed of the option to delay sexual activity until they are ready (matured), youths understand the importance of using condoms if sexually active, there is a reduction of new HIV/AIDS/ other STI infections, and reduction in unwanted teenage pregnancies.

\section{Conclusion}

HIV/AIDS programmes on youth's sexual health are interventions that aim at halting the transmission of HIV/AIDS and enhancing the sexual health of the youths. These programmes usually focus on preventing the spread of HIV/AIDS epidemics through a complementary combination of behavioural, biomedical and structural strategies. The decline of HIV/AIDS infections among youths has slowed drastically in the past decades, which indicates the need for increased funding and scale-up services. For maximum positive impacts and effectiveness, HIV/AIDS programmes need to be targeted at the youths who are the flashpoint and at high risk of contracting the epidemics due to their unwholesome sexual habits. It is evident that effective implementation of HIV/AIDS programmes needs to take into account underlying socio-cultural, economic, political, legal and other contextual factors, hence this will enhance the protection of the youths against the disease, thereby improving their sexual health as well as curtailing the transmission of HIV/AIDS globally.

\section{Recommendation}

Based on the findings of this study the following recommendations are made:

I. The Government and Non-Governmental Organizations (NGO's) should embark on a sensitization /awareness campaign on the impacts of HIV/AIDS programmes on the sexual health of the youths.

2. Future interventions need to focus on attitudes and correction of misconceptions about HIV/AIDS in youths. These interventions may be impacted by good sexuality education in schools. Including HIV/AIDSrelated subjects in the curriculum may be somewhat effective.

3. The role of the media cannot be overemphasized but the roles of parents and teachers (who are not in the habit of teaching anything related to sex) are very enormous in this issue. Indeed, it is difficult to change attitudes but a focus on the proper use of condoms will be more practical.

4. There should be a positive attitude among the youths towards sexual health or HIV/AIDS preventive strategies/measures which could produce desirable behaviours and reduce risk.

5. The youths should exhibit good sexual habits to enhance their sexual health and protect them from contracting HIV/AIDS and other Sexually Transmitted Diseases (STDs) or Infections (STIs).

6. There should be adequate funding of HIV/AIDS programmes and interventions by relevant agencies to make the programmes a success and their objectives realized.

\section{References}

Abiona, T.C., \& Odu, O.O. (2018). My College Students in Nigeria Underestimate their Risk of Contracting HIV/AIDS Infection. The European Journal of Contraception and Reproductive Health Care; $12(2) ; 131-13713$.

Adeyi et al. (2010).'AIDS in Nigeria: A Nation on the Threshold'.Chapter 2: The Epidemiology of HIV/AIDS in Nigeria Harvard Center for Population and Development Studies. HIV/AIDS in Nigeria. Avert International. Accessed: http://www.avert.org/aidsnigeria.htm 18. 
Adih, W.K., Alexander, C.S. (2009). Determinants of Condom use to Prevent HIV Infection among Youths in Ghana. Journal of Adolescent Health; 24 (1):63-72. [Pubmed] [Google Scholar]

Allman, D., Adebajo, S., Myers, T., Odumuye, O. \& Ogunsola, S. (2007). Challenges for Sexual Health and Social Acceptance for Men who have Sex with Men in Nigeria. Culture, Health and Sexuality; 9 (2): 153- 68. 16.

Amuyunzu-Nyamongo M, Biddlecom, A.E, Ouedraogo, C., Woog, V., (2015). Protecting the Next Generation: Understanding HIV Risk among Youths. Qualitative Evidence on Youths' Views of Sexual and Reproductive Health in Sub-Saharan Africa. Occasional Report No. 16. [Google Scholar].

Ijadulunola, A. (2017). Impact of Knowledge of HIV/AIDS Programmes on the Sexual Health of the Youths in Kenya. Journal of Biosocial Science. 2003; 35(3):385-411. [Pubmed] [Google Scholar]

Mbagwu, I., \& Abali, S.O. (2017). Assessment of HIV/AIDS Awareness and Changes in Sexual Practices among Secondary School Students in Nsukka Environment. Tropical Doctor Journal; 37: 268-270 3. Mass F,

National Agency for the Control of AIDS (NACA) (2010). 'National HIV/AIDS Strategic Framework (NSF): Knowledge of Sexual Health among the Youths; 2010-15' 19. WHO.

Nwokocha, A. \& Nwakoby, B. (2012). Knowledge, Attitudes and Behavior of High School Students Concerning HIV/AIDS in Enugu, Nigeria. Journal of Pediatric Adolescent Gynecology; 15: 93 - 969.

Okojie, O.H. (2016). Knowledge of HIV/AIDS and Sexual Practices among Adolescents in Benin City, Nigeria. African Journal of Reproductive Health; 10 (3): 76- 838.

Okudo, J. (2012). "Knowledge and Attitudes of Youths in Nigeria about HIV/AIDS- A Systematic Review" Digitalcommons@TMC, School of Public Health, Dissertations (Via Proquest). Paper 1. https://digitalcommons.library.tmc.edu/uthsph_dissertations/1

Samuelsen, H. (2006). Love, Lifestyles and the Risk of AIDS: the Moral Worlds of Youths in Bobo-Dioulasso, Burkina Faso, Culture, Health \& Sexuality; 8(3):211-224. [Pubmed] [Google Scholar]

UNAIDS (2012). 'Update: Active Involvement of Youths Is Key to Ending the AIDS Epidemic by 2030'

Venier, J.L, Ross, M.W, \& Akande A. (2018). HIV-Related Anxieties in Adolescents in three African Countries. Social Science and Medicine, 46, 313 - 320 24. United States Agency for International Development (USAID)/Nigeria. HIV/AIDS Health Profile October, $2010 \quad$ Accessed: http://www.usaid.gov/our_work/global health/aids/countries/afric a/nigeria.pdf

World Health Organisation (WHO) (2013). 'HIV And Youths: Guidance for HIV Testing and Counselling and Care for Youths Living with HIV'

World Health Organization (WHO) (2013). Child and Adolescent Health and Development $(\mathrm{CAH})$. Youths-A Window of Hope in the HIV/AIDS Pandemic. Available from: http://www.who.int/childadolescent-health/hiv/hiv_youths.htm.

World Health Organization (WHO) (2014). National AIDS Programs: A Guide to Indicators for Monitoring and Evaluating National HIV/AIDS Prevention Programs for Youths. Geneva: [Google $\underline{\text { Scholar] }}$

World Health Organization (WHO) (2017). Child and Adolescent Health and Development $(\mathrm{CAH})$. Youth - A Window of Hope in the Hiv/Aids Pandemic. Available from http://www.who.int/childadolescent-health/HIV/HIV-adolescents.htm. 


\section{Appendices}

Questionnaire on Assessing Impacts of HIV/AIDS Programmes on Sexual Health among Youths of Obiyebe Community in Ogba/Ebgema/Ndoni Local Government Area of Rivers State

SECTION A: Respondent's Socio-demographic Data:

Instruction: please complete the following as it reflects your response by ticking $V_{\text {in }}$ the appropriate box.

1.

Age: a) $15-20 \mathrm{yrs} \square$ b)

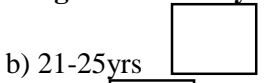

c) $26-30 \mathrm{yrs}$

d) $31-35 \mathrm{yrs}$

e) $36-40 \mathrm{yrs}$

2. Sex:

a) Male

f) 41 and above

3. Educational qualification: a) Primary

b) Female

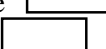

d) Others

4. Occupation: a) Students

c) Unemployed<smiles>C1CCC1</smiles>

d) Self-employed

5. Marital Status: a) Single

d) Widow/widower<smiles>[CH]1CCC1</smiles><smiles>C1CCC1</smiles>

b) Married

b)Secondary

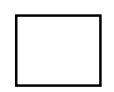

c) Tertiary

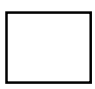

6. Religion:

a) Christianity

e) Separated

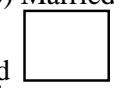

d) Others

b) Islamic

c) Traditional

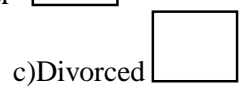

SECTION B: Research Questions

Legend: A: Agreed $\quad$ S.A: $\quad$ Strongly Agreed D: Disagreed S.D: $\quad$ Strongly Disagreed.

I. What are the HIV/AIDS Programmes on Sexual Health?

\begin{tabular}{|c|c|c|c|c|c|}
\hline $\mathbf{S} / \mathbf{n}$ & Items & $\mathbf{A}$ & S D & D & S D \\
\hline 1 & $\begin{array}{l}\text { HIV/AIDS prevention programmes i.e. voluntary medical male circumcision } \\
\text { etc }\end{array}$ & & & & \\
\hline 2 & United Nations Programmes on HIV/AIDS (UNAIDS) & & & & \\
\hline 3 & HIV/AIDS treatment programmes & & & & \\
\hline 4 & HIV/AIDS testing programmes & & & & \\
\hline 5 & Technology and e-health programmes & & & & \\
\hline
\end{tabular}

II. What is the Knowledge of Sexual Health among the Youths?

\begin{tabular}{|l|l|l|l|l|l|}
\hline $\mathbf{S} / \mathbf{n}$ & Items & A & S.A & D & SD \\
\hline 1 & Adolescence and puberty & & & & \\
\hline 2 & Sexual anatomy and sex & & & & \\
\hline 3 & Sexuality & & & & \\
\hline 4 & STIs/STDs & & & & \\
\hline 5 & Condoms & & & & \\
\hline 6 & Inclusive sex education & & & & \\
\hline 7 & Choosing not to be sexually active right now & & & & \\
\hline
\end{tabular}

III. What are the Impacts of HIV/AIDS Programs on Sexual Health of the Youths?

\begin{tabular}{|c|c|c|c|c|c|}
\hline $\mathbf{S} / \mathbf{n}$ & Items & $\mathbf{A}$ & $\mathbf{S A}$ & D & S D \\
\hline 1 & $\begin{array}{l}\text { Youths are informed on normal adolescent development, puberty and } \\
\text { reproductive anatomy and physiology }\end{array}$ & & & & \\
\hline 2 & Youths understanding on sexuality is increased & & & & \\
\hline 3 & $\begin{array}{l}\text { The youths are informed of the option to delay sexual } \\
\text { activity until they are ready (matured) }\end{array}$ & & & & \\
\hline 4 & $\begin{array}{l}\text { HIV/AIDS programmes help the youths to understand } \\
\text { the importance of using condoms if sexually active }\end{array}$ & & & & \\
\hline 5 & There is reduction of new HIV/AIDS/ other STI infections & & & & \\
\hline 6 & There is also reduction in unwanted teenage pregnancies & & & & \\
\hline
\end{tabular}

- Thank you for publishing with us. 